Lepr Rev (1991) 62, 1-12

\title{
Editorial
}

\section{LEPROSY STIGMA}

Stigma has been defined by Goffman ${ }^{1}$ as an attribute that is deeply discrediting, and the stigmatized individual is one who is not accepted and not accorded the respect and regard of his peers; one who is disqualified from full social acceptances. Goffman uses the term 'discreditable individual' for the person who assumes his differentness is neither known about by those present nor immediately perceivable by them, and he goes on to describe three main groups of stigmatized individuals. Firstly, those with physical deformities, particularly of the face. Additional examples are scars on the wrists of those who have attempted suicide, and the injection marks on the arms of drug addicts. Secondly, those with blemishes of character, inferred by a history of mental disorder, epilepsy, imprisonment, drug addiction, alcoholism, homosexuality, unemployment, suicidal attempt, and radical political behaviour. Thirdly, those with tribal stigma of race, nation, social class, and religion.

\section{Leprosy stigma}

Applying Goffman's definitions to leprosy, we can see that all of his three groups of stigmatized individuals are encompassed by the one disease: in the group with physical deformities we have the face of the neglected lepromatous patient, the facial plaque of the nonlepromatous patient (especially if in reaction), facial palsy, claw hand deformity or footdrop (both of which may identify the leprosy sufferer in an endemic country), or the hypopigmented macules which are so conspicuous on a dark skin. In the group with blemished character we have segregation in a leprosarium, or a history of such segregation. For Christian and Jewish communities we can add the use of the word 'leprosy' in the Bible as a punishment for sin. In the group with tribal stigma we have the immigrant worker in, say, a country of Western Europe, who has been found to have leprosy; not only is he a foreigner but he is likely to have a pignented skin and to belong to the working class, factors which render him 'inferior'. He may even not be a Christian. The 'tribal' factor in countries where leprosy is endemic is poverty, for society looks upon leprosy as a disease of poverty. 


\section{The history of leprosy stigma}

Leprosy stigma is as old as the disease, for when leprosy was recognized as a clinical entity in India and China about $600 \mathrm{BC}$ it arose as an instinctive social reaction to a disfiguring, progressive, and incurable disease; not only has this reaction persisted up to modern times but the disease has been additionally stigmatized over the centuries. Skinsnes puts it in these words: ${ }^{2}$

'The pattern of social abhorrence and persistent reaction to leprosy is unique among diseases in its intensity, inventiveness and ubiquity. ... The presence of this reaction and behaviour pattern is not an evidence of unique racial or national benightedness but is remarkably similar in major cultures of both the Orient and the Western World and reaches far back into antiquity.'

In Western Europe leprosy stigma reached its apotheosis in the Middle Ages when the leprosy sufferer was considered by society and the Church as 'unclean', was denied civil rights, and was expected to dwell in a lazar house or hospital situated 'outside the camp' (outside the city wall). ${ }^{3}$,

British Isles between 1000 and $1500 \mathrm{AD}$, I would draw attention to the on-going excavations which began in 1986 in the burial ground of the hospital of St James and St Mary Magdalene near Chichester, Sussex, half a mile north-east of the old city wall. A preliminary report in $1989,{ }^{5}$ states that of the 351 individuals exhumed, 83 skeletons $(24 \%)$ have exhibited changes compatible with a diagnosis of leprosy. This lazar hospital was founded before 1118 and functioned for at least 300 years. This was a time when, according to Richards, 'leprosy was regarded as moral or spiritual contagion rather than as a disease which could be transmitted from one person to another.' Leprosy reached its peak later in Denmark, for St Jorgen's Hospital in Naestved, the only one of 30 lazar hospitals so far excavated in that country, functioned between 1250 and 1550 AD.

An explanation has to be found for the fact that leprosy stigma in Britain, so prevalent in the Middle Ages, disappeared with the dying out* of the disease af ter the end of the 15th century, yet the taint of leprosy reappeared a few centuries later, and by the end of the 19th century stigma had caused Western nations to panic. Gussow ${ }^{6}$ calls it the 'retainting' of leprosy and explains that it was due to a combination of events, chief of which was the discovery of hyperendemic leprosy in the colonial world. The imperialist countries of Western Europe were, during the second half of the 19th century, conquering large areas of Africa, Asia, and Polynesia, and were reporting that leprosy was hyperendemic among the 'inferior' people inhabiting their colonies, with the risk that the disease might contaminate the civilized world. The germ theory of disease, and Hansen's discovery of the leprosy bacillus in 1873, added fuel to the view that leprosy was highly contagious, a view which still has not been entirely dispelled. Furthermore, this was a period of religious revival in England. Intensive missionary activity prompted community interest in the 'leper' and established leprosaria in all the regions where they ministered. Support for Gussow's theory of the retainting of leprosy comes from a communication of mine, written jointly with Bridgett Jones, ${ }^{7}$ describing cases of psoriasis diagnosed and recorded

\footnotetext{
* The term 'dying out', as applied to Western Europe, must not be taken literally, for an isolated focus of leprosy persisted in the Shetland Isles of Scotland up to 1798, and no doubt a similar situation held good in France and explained how the early French settlers took the disease to Canada.
} 
as 'leprosy' in the Manchester Infirmary, England, between 1750 and 1770. There was no adverse reaction on the part of these patients to a diagnosis of leprosy. Fears that leprosy would spread from colonial territories to the countries of Western Europe proved unfounded, for the immigration of workers from endemic countries has not caused the anticipated epidemic; in fact, apart from one indigenous case reported from France ${ }^{8}$ and another from the Netherlands in a male engaged in the delivery of milk to householders in a Dutch city containing many immigrants, leprosy has been confined to immigrants and to the occasional national who has been infected during residence in the tropics. Abel \& van Soest ${ }^{9}$ have described their experience in treating immigrant workers and overseas students suffering from leprosy in the German Federal Republic. They explain that any illness poses a threat to their existing labile equilibrium, and if the disease is leprosy the disturbance of equilibrium is almost predictable: 'in nearly all cases we have observed that communication of the diagnosis caused a crisis'. They describe the initial despair of these patients, causing depression in some and aggression in others; all thought their situation 'catastrophic' or 'hopeless', and an Italian patient saw his illness as 'God's punishment'. A patient from Jordan was in real danger of suicide. Misconceptions about leprosy were not confined to these patients for they also were held by the general population, the two most common being that the disease was incurable and extremely infectious, and some Christian groups connected it with divine punishment. Their report ends with this plea: 'As much attention should be paid to the psychologic and social problem of these patients as to their somatic ones'. Reports of the postwar leprosy situation in France ${ }^{10}$ and in the Netherlands ${ }^{11}$ have been published.

\section{Some encounters with leprosy stigma in England}

\section{STIGMA AMONG PATIENTS}

Case 1. A 27-year-old male who had emigrated from India was given a kidney transplant in Addenbrooke's Hospital, Cambridge, for end-stage renal failure, but did not divulge that he had been treated for leprosy in his home country between the ages of 13 and 17 , since when he had taken an occasional dapsone tablet. Two years later I was asked to see him, and I found him to have active lepromatous leprosy (LL) complicated by type 2 lepra reaction (with ENL and unilateral epididymo-orchitis). He responded well to treatment, but two and a half years later his renal function deteriorated, and after several months of haemodialysis he died of pulmonary infection and liver failure. ${ }^{12} \mathrm{Had}$ leprosy stigma not prevented him from giving a true medical history to his doctors in Cambridge, the outcome might have been very different.

Case 2. A 60-year-old male came to England with his family on his retirement from Indian Railways. A few years later he became a regular attender at his local hospital because of a chronic plantar ulcer, denying having had any illnesses in the past. The ulcer enlarged to such an extent that a below-knee amputation was carried out. The result was disastrous as his doctors had not noted the anaesthesia of his legs extending to his thighs, so whenever he attempted to wear his prosthesis he developed ulceration of his stump. Nodules appeared on his skin the following year, and when I saw him he admitted having been treated with dapsone for ten years in his home country.

Case 3. When a young male was told in India that he had leprosy, his aggressive reaction was to set out with his motorcycle on a world tour. Travelling through Iran, the 
Soviet Union, across Europe from east to west, then taking ship to North America, he continued his road journey until he reached Calgary, in South West Canada, where he was hospitalized with a diagnosis of lepromatous leprosy (LL). The Canadian Government repatriated him, whence he promptly flew to London where he came under my care as a case of advanced LL with gross deformity of his fingers.

Case 4. An Englishman who had spent his working life in India came home to retire in the 1950s. He brought with him his two sons aged 17 and 15 respectively. The elder son was found, soon af ter arrival, to be suffering from borderline leprosy, but as he could not face up to the diagnosis he sought escape from his dilemma by joining the British Army. This he did (with his father's approval) and enlisted for seven years. During his service he attained the rank of sergeant, and it was only at final medical examination seven years later that his secret was revealed. He was admitted to the Jordan Hospital* with active LL and gross ulceration of both lower legs - see the illustration of ulcerated legs in the first four editions of Textbook of Dermatology. ${ }^{13}$

Case 5. A young Indian scientist working in London was greatly distressed on being told that the erythematous plaque on his face was due to tuberculoid leprosy (TT). Outpatient therapy with dapsone resulted in disappearance of the lesion af ter one year, and it was then that he admitted that he would have committed suicide had the diagnosis been made in his home country.

Case 6. On one occasion at the Jordan Hospital I received a telephone call at midnight from a provincial hospital requesting urgent admission of a Maltese male whose suicide attempt had just been foiled!

Case 7. Of three suicide attempts at the Jordan Hospital, only one was successful. The patient, a well-educated Indian male, was admitted with a diagnosis of leprosy and committed suicide that same night, leaving a note admitting that he could not face life with leprosy.

\section{STIGMA AMONG PATIENTS' RELATIVES}

An Italian engaged in the wool trade in Yorkshire went to his home country in 1960 and brought back a wife, but during her first pregnancy she was admitted to the Jordan Hospital with active LL. She and her husband were bewildered by the tragic turn of events, and it was only when she showed her family photograph to the senior nursing sister that the explanation was plain to see: in the centre of the group stood her father, and his face bore the stigmata of LL in the presulphone era. The patient recalled her father's visits to Genoa every six months, but had never been told the reason. A second example was that of a middle-aged, single English lady, born into a prominent family in the Caribbean, who was referred to the Hospital for Tropical Diseases in London. She was found to have LL and was transferred to the Jordan Hospital. So great was her family's fear of being stigmatized by leprosy that all contact with her ceased, apart from a regular remittance. When the time came for her to be discharged, sheltered accommodation was

\footnotetext{
* When the National Health Service was established in 1948 in Britain the then Minister of Health, worried by the influx of workers and students from the tropics, decided to make leprosy notifiable and to open a specialized hospital for leprosy patients requiring in-patient management, so the Jordan Hospital (named after the Biblical river of healing) was opened in 1950, with accommodation for 24 patients. It was situated in Earlswood, Surrey, a rural area 26 miles south of London, and it was closed in 1968 for reasons other than shortage of patients for it functioned to full capacity throughout its working life.
} 
found for her in London, but so great had been her isolation, and so great the stigma, that she became a recluse and died prematurely.

\section{PUBLIC MISCONCEPTIONS ABOUT LEPROSY}

In 1950 when the Redhill-Reigate district of Surrey heard that their Victorian infectious diseases hospital in the village of Earlswood, no longer functioning, was being converted into a leprosy hospital, a protest group was formed. It took several public meetings, and the strong support of the then local Medical Officer of Health, Dr Bingham, to carry through the project. At the end of that year I moved into the doctor's house with my family, and although two of my children obtained places as day scholars at a local school, three years passed before any local children were allowed by their parents to visit the doctor's house. Later events affecting two of my patients can be recorded here. The first one involved a Maltese patient who had been treated at the Jordan Hospital and, on discharge, obtained a post in the office of an insurance company in Reigate, only to be summarily dismissed when the manager heard about his leprosy. The second event involved a female patient at the Jordan Hospital who was told by her husband that their two children had been expelled from their London school when the headmistress heard that their mother was being treated for leprosy. Both these unjust acts, prompted by misconceptions about leprosy, were resolved by diplomacy.

\section{Leprosy and stigma in other European countries}

\section{SCANDINAVIA}

In Denmark, where leprosy was an important endemic disease in the Middle Ages, involving the establishment of over 30 St Jorgen's (St George's) hospitals, only one of these has been systematically excavated, namely, St Jorgensgaard, near Naestved..$^{14}$ It functioned as a leprosy hospital between the years 1250 and $1550 \mathrm{AD}$, later than leprosy hospitals in England. In the countries further north it was an endemic disease of minor importance in the Middle Ages, but reached a peak by the middle of the 19th century with an overall prevalence in Norway of 1.67 per thousand, ${ }^{15}$ and Gussow quotes figures reaching 70 per thousand in parts of the hyperendemic western districts. ${ }^{6}$ The great increase in the number of lazar homes and hospitals in Norway during the 19th century (the St Jorgen's Hospital in Bergen having been established in the 15th century) had the objective of preventing procreation, for the Norwegian medical profession firmly held to the view that leprosy was a hereditary disease, even for a decade or two after Hansen's discovery of the leprosy bacillus in 1873 . Therefore in-patients were free by day to sell their handwork in the market or to entertain visitors, so long as they conformed to segregation at night. Hence there was little evidence of stigma, ${ }^{6}$ and Hansen was able to write: 'the Norwegian state has always handled its leprosy victims humanely'. ${ }^{16}$ The motivation for many Norwegian families to emigrate to the Upper Mississippi Valley of the United States, beginning in the 1820 s, was poverty rather than leprosy stigma, although it is likely that leprous adults may have had the additional motivation of avoiding sexual segregation. The reason for the disappearance of leprosy from Norway and neighbouring Scandinavian countries is still open to debate. ${ }^{17-19}$ 


\section{SOUTHERN EUROPE}

In contrast with Western Europe, leprosy did not die out after the end of the 15th century but has persisted as a minor endemic disease in all Southern Europe from Portugal in the west to Greece in the east. Leprosy stigma has persisted, with patients adding to the difficulties of eradication by keeping their disease secret. Spain has the highest prevalence and possesses the largest leprosarium in Europe-Fontilles in Alicante-where treatment is combined with teaching and research of international repute.

\section{EASTERN EUROPE}

In Imperial Russia, as in Scandinavia, leprosy reached a peak in the 19th century, and news of leprosy in Siberia was brought to Britain by an English nurse named Kate Marsden who, with Christian zeal and self-sacrifice, made a perilous journey to Siberia in 1891 to acquaint herself with the position of leprosy sufferers there and to arouse the public and official conscience in Russia to their terrible plight. ${ }^{20}$ On her tour of the Yakutsk Province of Siberia she found small groups of these unfortunate people living as exiles scattered throughout the forests, having been expelled from their villages. Each group shared a single hut in which they existed, naked or in rags, the strongest members of the group going out to fetch whatever scraps of food their healthy relatives would leave for them at an appointed place in the forest. On her return to Moscow and St Petersburg Miss Marsden raised funds for building a leprosarium so that those driven into the forests could be brought into proper shelter where they could receive food, clothes, and nursing care.

A recent issue of Leprosy Review ${ }^{21}$ carried a report about the Tichilesti Leprosy Colony in present-day Romania, a colony which was opened in 1877 with a capacity for one hundred inmates. At present it contains 54 patients, with equal numbers of men and women, mostly elderly. The most recent admission was four years ago. The medical superintendent anticipates a few more admissions now that medical information is freely available, but the reader is left wondering how many leprosy sufferers are avoiding incarceration by keeping their disease secret.

\section{Leprosy misconceptions and stigma in countries outside Europe}

INDIA

The earliest reliable evidence of leprosy in India can be found in the Susruth Samhita written about $600 \mathrm{BC}$, the most complete and accurate of the old descriptions, even mentioning chaulmoogra oil as treatment. ${ }^{22}$ As for the present-day situation, Mutatkar ${ }^{23}$ outlines the situation as follows:

1 The concept of heredity is deeply rooted in Indian culture since the social structure is based on the principle of hereditary inequality, making it difficult to change people's misconceptions about the hereditary nature of leprosy.

2 The Hindu view considers deformity as divine punishment, and people equate gross deformity with leprosy. This misconception is encouraged by the fact that patients who recover, and appear perfectly normal, keep their disease secret. 
3 The Indian medical profession looks on leprosy as a disease apart and keeps away from it, tending to share public misconceptions.

4 Deformed beggars reinforce the association between leprosy and poverty.

5 Many misconceptions are held by the general public, some contributing to stigma, therefore educating the public and the medical profession on the true facts about the disease is the paramount necessity in order to overcome ignorance and prejudice. 'The problem with leprosy is not what the disease is, but what the people believe it to be'.

India's National Leprosy Eradication Programme (NLEP), ${ }^{24}$ and its objective of getting the disease under control, is a welcome development.

\section{CHINA}

Earliest records of leprosy in China date back to about $500-300 \mathrm{BC}^{25}$ and up to relatively modern times the disease has met with social opprobrium because of its unique nature. Skinsnes ${ }^{2}$ lists facial disfigurement, mutilation of limbs, chronicity and long incubation period causing mystery about its origins, inspiring horror, fear and disgust. Misconceptions added their quota to leprosy stigma, particularly the belief that it was transmitted by sexual relations with prostitutes and therefore was punishment for moral lapse. During the second half of the 19th century and the first half of the 20th, there was intense missionary activity in China, and care of leprosy sufferers had a prominent role. At the time of founding New China in 1949 there were 40 leprosaria in existence, 39 established by foreign missions, with accommodation for about 2400 patients. ${ }^{26}$ Since the early 1950 s the Chinese Government has taken over all leprosy work, and up to the time of his death in 1988 Dr Ma Haide (George Hatem) headed the campaign aimed at eradicating the disease by systematic diagnosis and treatment throughout the country, using standard drug regimens and $\mathrm{BCG}$ vaccination. He estimated that there were about 600,000 cases at the beginning of the campaign, and its thoroughness is shown by Yang Lihe's figure of less than 100,000 in $1983 .{ }^{27}$ Another important statistic is that the proportion of new cases belonging to age groups less than 15 years has decreased from $16 \cdot 0 \%$ (1955) to $0 \cdot 16 \%$ (1984). ${ }^{27}$ All Chinese commentators anticipate that basic eradication will be attained by the end of the century. With this decline, and the additional campaign of education and propaganda, leprosy stigma has likewise declined.

\section{NORTH AMERICA}

Canada Canada provides three interesting facets of leprosy history. Firstly, from 1639 onwards immigrants from France settled in the province of New Brunswick, and the first case of leprosy was diagnosed in $1815^{28}$ or $1817^{29}$ in a young married woman, Ursule Benoit. Other cases were occurring, and a medical commission in 1844 reported that the 'loathsome disease' was infectious and patients should be segregated. A lazaretto was established on an island in the river Miramichi, and in 1896 a modern hospital was built in Tracadie. ${ }^{29}$ The leprosy epidemic ended in 1937 when the last two patients were admitted, 120 years after the disease was encountered. Secondly, turning our attention to the neighbouring province of Nova Scotia, many Scottish settlers arrived from the Hebrides and Shetland Isles after the British authorities expelled the French settlers (Acadians) in 1755. Leprosy was diagnosed in 1852 in a Mrs Betty MacArthy of Cape Breton, ${ }^{30}$ and the 
fact that she was English proves, to my mind, that there was at least one earlier undiagnosed case in that region, for there was no leprosy in England in the 19th century. In Scotland, on the other hand, leprosy was endemic in the northern islands until the end of the 18th century. We have Ashmead's ${ }^{30}$ assurance that there was no leprosy among the Micmac Indians at that time. Thirdly, Canada provides an intriguing proposition: if Acadians had not been expelled from Nova Scotia in 1755 there would be no Carville today in the United States- see below.

The United States The origins of a leprosy problem in the United States dates back to the introduction of the disease by French settlers (Acadians) who emigrated to southern Louisiana when they were expelled from the Canadian province of Nova Scotia by the British authorities in 1755 . Gussow ${ }^{6}$ has fully documented the subsequent story, beginning with the Louisiana legislature establishing in 1884 a State Board of Leprosy Control which was directed to find a 'Leper Home'. The Board obtained a 5-year lease on 'Indian Camp', an abandoned plantation bordering the Mississippi river and about 85 miles north-west of New Orleans. They named it the Louisiana Home for Lepers, and the first patients were admitted at the end of that year. The Board intended to find a permanent site nearer the capital city, but met with such public opposition that they gave up the task and, in 1905, the state of Louisiana purchased Indian Camp. In 1917 the US Congress passed a bill to create a national leprosarium, and in 1921 the Louisiana Home for Lepers became under US federal jurisdiction as the US Marine Hospital, Carville,.a sanctuary and refuge for leprosy sufferers throughout the country, with admission on a voluntary basis. The patients had no doubt that leprosy stigma created Carville, and in subsequent years, under the leadership of Stanley Stein who founded the crusading journal The Star, they organized their energies and talents to combat stigma. In the 1940s, Carville came into prominence by discovering the first effective antileprosy drug, a sulphone named Promin, and since then has combined the housing and treatment of patients with an expanding programme of teaching and research. Since the early 1960 s a number of diagnostic and treatment clinics for out-patients have been set up in those states favoured by foreign immigrant workers, and Gussow 6 reports a study in the mid1960s which reported that strong public stigma could not be demonstrated. Today leprosy is a minor endemic disease in two American states, Louisiana and Texas, the latter state (and its endemic leprosy) having been annexed from Mexico in 1848.

\section{THE CARIBBEAN}

The island of Trinidad has provided an extreme example of leprosy arousing fear and prejudice in official circles, demonstrated in events which, inexplicably, were largely ignored by the medical press; the only report I have been able to locate was in The Star of February $1955 .{ }^{31}$ The events occurred at Christmas 1954 extending to January 1955 when Dr Michael Corcos, the recently appointed Medical Superintendent at Chacachacare, an island leprosarium where compulsory segregation was the rule, allowed 130 patients to spend the festive season with their families. Some members of the Trinidad Legislative Council promptly called for his 'immediate removal or suspension'. The local press gave generous cover to 'the flood of patients let loose in the community' but was muted in its criticism of the Superintendent. On 7 January 1955 the Governor dismissed him and ordered him to leave Chacachacare with his family, and the patients responded with a protest 'sit-down' strike. Armed police were rushed to the island, and after five 'ring 
leaders' had been taken into custody the strikers were persuaded to resume their normal routine. Although the immediate result of these events was the departure from Trinidad of Dr Corcos, a long-term result was the decision of the Government of Trinidad and Tobago in 1968 to close the leprosarium and to set up a Leprosy Control Programme. Diagnostic and treatment clinics were set up on the twin islands of Trinidad and Tobago in 1971 , and by 1981 the numbers of known cases had fallen from $1638(16 / 10,000)$ to 763 $(7 / 10,000)$, together with a significant reduction in new cases in children. ${ }^{32}$ The success of this Programme has led to an improved official and public attitude to leprosy. Turning to Guyana, a present-day urban community was asked a series of questions about diseases of the community, and on leprosy the great majority considered it to be incurable, disfiguring, shameful and fear-inspiring. The author ${ }^{33}$ proposes that in the campaign to eradicate leprosy stigma the two essentials are:

1 the general public must be persuaded that it is curable: and

2 treatment must be on an out-patient basis.

\section{Factors contributing to leprosy stigma}

It is generally agreed that leprosy stigma handicaps the eradication of the disease, so let us consider the factors contributing to it:

1 The general public worldwide has many misconceptions about leprosy, some contribute to stigma, therefore health authorities in endemic countries, and in countries where leprosy is a disease of immigrants, should launch an information campaign stressing that the disease is curable and that patients on treatment are noninfectious. Religious leaders should explain to Christian and Jewish communities that 'leprosy' in the Old Testament, a divinely ordained punishment for $\sin$ (Leviticus 13 and 14), is not mycobacterial leprosy. ${ }^{34-36}$

2 The medical profession in many endemic countries looks upon leprosy as a disease apart, thus it is unable to contribute to the dispelling of public misconceptions. Leprosy must be given a more important place in the curriculum of medical students in endemic countries. ${ }^{37-39}$ In nonendemic countries which have immigrant workers, dermatologists have a unique opportunity to diagnose early leprosy cases, therefore a sound knowledge of the disease should be a priority in their specialist training.

3 Leprosaria and leprosy colonies have, in the past, played a role in promoting and sustaining stigma, and additionally have done little to reduce leprosy incidence (the exception of 19 th century Norway has already been discussed). Their closure over recent decades and replacement by suitably-sited out-patients clinics has been a welcome advance. A few 20th century leprosaria, like Carville in the United States and Fontilles in Spain, are exceptions in that there is no strict segregation and the institutions are centres of world renown in teaching and research.

4 Leprosy patients who have no signs detectable by the general public, and cured patients who look healthy, keep the diagnosis secret ${ }^{40}$ and thereby contribute to leprosy stigma by allowing the public to gain an entirely wrong impression of the disease; they see it as incurable and inevitably disfiguring. This misconception is compounded when burntout cases beg for a living. Mutatkar ${ }^{23}$ states that in 1962 the Gandhi Memorial Leprosy Foundation estimated that of the 5000 leprosy patients in Poona about 400 were beggars. 5 Laws discriminating against leprosy sufferers add their quota to stigma. For example, 
India's Leprosy Act of 1898 was formulated to protect the public health by restricting their activities, and even though some states have repealed this Act it still exists in about ten (although for many years it has not been enforced). Another example is the Hindu Marriage Act of 1955 which permits divorce if a spouse is suffering from 'a virulent or incurable form of leprosy'; it is still in force, as are the Muslim Marriage Act, the Indian Christian Marriage Act, and the Special Marriage Act, all of which have similar provisions for divorce. ${ }^{41}$

6 Writers, journalists and politicians promote stigma when they use the words 'leprosy', 'leper' or 'leprous' to imply something evil, degrading or immoral, and many examples in English literature since the time of Chaucer have been supplied by Skinsnes and Elvove. ${ }^{42}$ Contemporary journalists have been prone to follow suit, and the most glaring example of stigma-activating journalism has been supplied on the front page of a British daily newspaper, The Sun, on 28 September 1989, apropos of the projected visit of the Princess of Wales to a leprosarium in Indonesia. The main headline 'DI TO SHAKE HANDS WITH A LEPER' was followed by a subsidiary headline, 'Don't do it, says $S U N$ doc'. A critical comment has appeared in the British Medical Journal (Figure 1).

7 Fund-raising agencies have, in the past, depicted the horrors of neglected leprosy in

Channel 4 Hard News 12 October

\section{Sweeping away superstition?}

The combination of royalty and a feared disease must have made an irresistible fron page story on 28 September for the editor of the Sun. Another headline, "Don't do it, say Sun doc," suggested that leprosy is extremely infectious, with an appreciable risk of transmission occurring by hand to hand contact. A catalogue of selected facts and misinterpretations then followed, emphasising the nastie aspects of the disease: "Sores multiply on the skin, nose and mouth," the incubation period can be as long as 20 years, it can lead to blindness, and a vaccine is impossible "since leprosy is a tuberculosis germ, but it cannot grow outside the body."

With a curiously heightened but merely momentary sensitivity to the feelings of leprosy patients, the article then continued by advising Princess Diana not to make a visit to a leper colony in Indonesia as "the lepers would be offended if she refused to shake hands or did it wearing rubber gloves." Unfortunately that sensitivity had dissipated by the next day, when the paper carried a grotesque cartoon of Princess Diana wearing an extendable arm to shake hands with a leprosy patient.

Hard News, a Channel 4 programme commenting on presentation of news items in the national press, on 12 October produced five minute piece in which a scientist, nurse, a former leprosy patient, and a leprosy worker were interviewed. It succeeded in correcting most of the misleading facts and impressions in the article. Dr Jo Colston, who is on the WHO leprosy committee, emphasised that multiple drug treatment, which has been recommended by WHO since 1981 , rapidly renders patients noninfectious. Additionally, as Indonesia actually has no leper colonies, it was speculated that the princess might perhaps be visiting a leprosy hospital, thereby contrasting the article's use of the stigmatising term leper colony, which has connotations of incurability and deformity, with the more positive emphasis on treatability implied by leprosy hospital.

Dr Vernon Coleman, the "Sun doctor," declined to appear on Hard News to defend his comments, as he was not prepared to travel for an appearance without a fee. In an interview with BBC Radio Essex, however, he admitted that his comments had been made under strict time constraints. $\mathrm{He}$ defended his estimate for the likelihood of contracting leprosy from shaking hands, "There's only a 1000 to one chance that she will catch it, but it's not worth the risk," as being merely "jargon for saying the risks are low." Had he watched the Hard News programme Dr Coleman would also have discovered, despite the "impossibility" of a vaccine, that at least four trials are currently in progress.

Hard News is to be congratulated on giving leprosy patients and their carers a much needed, valued, and appropriate right of reply to a peculiarly distasteful piece of tabloid journalism, but I suspect that only a minority of Sun readers will have seen the programme. Despite the corrections made by Hard News, there may be longer term effects of such newspaper articles. Their prominence on the front page, presumably because no

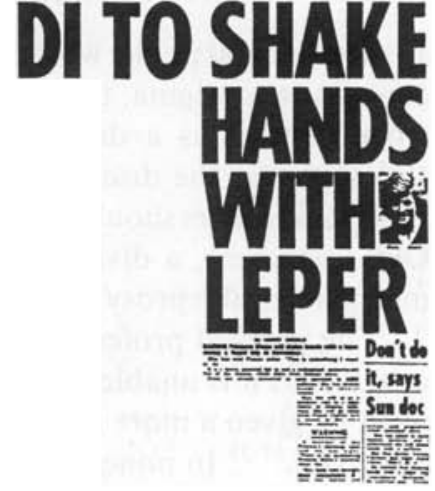

juicier news item is available; the size of the newspaper's readership; and the article's viewpoint, wrapped up in an overly sanctimonious and manifestly hollow concern for royalty, can only have reinforced the traditional prejudices and deeply felt fears derived from ignorance that have accompanied this disease since ancient times. More serious for the medical profession is the realisation that the article derived its power and respectability solely from the manner in which its conceptions of leprosy had been sanctioned by a single non-specialist practitioner, who apparently had had to rush to meet tight deadlines. Without that legitimisation the article would have carried little weight. In any event it can have done little to further Princess Diana's stated intention of "sweeping away superstition and prejudice."-DIANA LOCKWOOD, Wellcome research fellon, London School of Hygiene and Tropical Medicine

Figure 1. The above is reprinted, with kind permission, from the British Medical Journal (1989), Volume 299, No. 6706, p. 1036. 
appeals in the press which have inadvertently encouraged stigma. A change of emphasis has been foreshadowed by an England-based leprosy Charity recently appealing for donations to aid treatment campaigns in the developing world: the headline ran 'LEPROSY CAN BE CURED'.

\section{Conclusion}

Just as medieval leprosy stigma disappeared from the countries of Western Europe with the dying out of the disease after the 15 th century $\mathrm{AD}$, so can present-day leprosy stigma disappear with the eradication of the disease by chemotherapy. A drive is necessary to get more endemic countries to use multidrug therapy MDT to the fullest extent because of its excellent results and the confidence inspired by a relatively short course of treatment. There is also a role for BCG vaccination at present and for a more effective vaccine in the future.

389a Holmesdale Road

W H JOPLING

South Norwood

London SE25 6PN

England

\section{References}

1 Goffman E. Stigma: notes on the management of spoiled identity. Englewood Cliffs: Prentice-Hall Inc., 1963. London: Penguin Books, 1968.

2 Skinsnes OK. Leprosy in Society III. The relationship of the social to the medical pathology of leprosy. Lepr Rev, 1964; 35: 175-81.

3 Browne SG. Some aspects of the history of leprosy: the leprosie of yesterday. Proc Roy Soc Med, 1975; 68: 485-93.

4 Richards P. The medieval leper and his northern heirs. Cambridge: D S Brewer Ltd., 1977.

5 Lee Frances, Magilton J. The cemetery of the hospital of St James and St Mary Magdalene, Chichester-a case study. World Archaeology. Archaeology of Public Health, 1989; 21: 273-82.

${ }^{6}$ Gussow Z. Leprosy, racism, and public health: social policy in chronic disease control. San Francisco \& London: Westview Press, 1989.

7 Jopling WH, Jones Bridgett EA. Psoriasis and leprosy. J Am Acad Dermatol, 1990; 22 Number 2, Part 1: 321.

${ }^{8}$ Godeau P, Wechsler B, Weisselberg C. Apropos d'un cas de lepre autochtone. Sem Hop, 1979; 55: 958-64. Abstracted in Excerpta Medica-leprosy and related subjects 1980; vol 2, issue 4, no. 483.

9 Abel G, van Soest AH. Psychologic difficulties in the treatment of leprosy patients in a nonendemic country. Int J Lepr, 1971; 39: 429-32.

10 Basset-Seguin N, Basset A. HD epidemiology during the last fifty years in France. The STAR, 1987; 46(4): 10.

11 Leiker DL. Epidemiology of leprosy in the Netherlands. Quad Coop Sanit, 1980; 1: 60-4.

12 Adu D, Evans DB, Millard PR, Calne RY, Shwe T, Jopling WH. Renal transplantation in leprosy. Br Med J, 1973; 2861: 280-1.

13 Jopling WH, Harman RRM. Leprosy. In: Textbook of Dermatology. Rook A et al. (eds). 4th ed. Oxford: Blackwell Scientific Publications, 1986: 823-38 (p. 827).

14 Moller-Christensen V. Ten lepers from Naesrved in Denmark. Copenhagen: Danish Scientific Press, 1953.

15 Irgens LM. Leprosy in Norway. Lepr Rev, 1980; 51 (Supplement 1).

16 Hansen GA. The memories and reflections of Dr Gerhard Armauer Hansen. Würzburg: German Leprosy Relief Association, 1976.

17 Irgens LM. Epidemiological aspects and implications of the disappearance of leprosy from Norway; some factors contributing to the decline. Lepr Rev, 1981; 52 (Supplement 1): 147-65.

18 Manchester K. Tuberculosis and leprosy in antiquity: an interpretation. Med Hist, 1984; 28: $162-73$.

19 Wood SR. A contribution to the history of tuberculosis and leprosy in 19th century Norway. J Roy Soc Med, accepted for publication.

${ }^{20}$ Marsden Kate. On sledge and horseback to outcast Siberian lepers. London: The Record Press, 1892.

21 News and Notes. Lepr Rev, 1990; 61: 204.

22 Lowe J. Comments on the history of leprosy. Lepr Rev, 1947; 18: 54-64. 
${ }^{23}$ Mutatkar RK. Society and Leprosy. Wardha (India): Gandhi Memorial Leprosy Foundation, 1979.

24 Rao CK, Dharamshaktu NS, Mittal BN, Choudhury SBR, Shah NK, Kumar S. National leprosy eradication programme in India: an independent evaluation. Indian J Lepr, 59: 203-18.

25 Skinsnes OK. Leprosy in Society II. The pattern of concept and reaction to leprosy in oriental antiquity. Lepr Rev, 1964; 35: 105-22.

${ }_{26}$ Ma Haide, Te Gan-yun. A general condition of the work on the prevention and treatment of leprosy in China. Int J Lepr, 1981; 49: 218-23.

27 Yang Lihe. 35 years of leprosy control in China and the future prospects for basic eradication of this disease. China Lepr J, 1986; 2:

28 Whitehead FL. 'Leprosy in New Brunswick: the end of an era. Canad Med Ass J, 1967; 97: 1299-1300.

29 Kato L, Marchand Jocelyne. Leprosy: 'loathsome disease in Tracadie, New Brunswick'-a glimpse into the past century. Canad Med Ass J, 1976; 114: 440-2.

30 Ashmead AS. Introduction of leprosy into Nova Scotia and the province of New Brunswick. Micmacs immune. JAMA, 1896; 26: 202-8.

31 Editorial. HD patients revolt at Chacachacare, Trinidad, B.W.I. The $S T A R, 1955 ; 11$ (No. 5 ): 4.

32 Keeler R, Deen RD. Leprosy in children aged $0 \cdot 14$ years: report of an 11 year control programme. Lepr Rev, 1985; 56: 239-48.

${ }^{33}$ Cook Anne. An urban community's thoughts about leprosy. A survey in Guyana. Lepr Rev, 1982; 53: $285-96$.

34 Lewis G. A lesson from Leviticus: leprosy. Man (N.S.), 1987; 22: 593-612.

35 Zias J. Lust and leprosy: confusion or correlation? Basor, 1989; 275: 27-31.

36 Lloyd-Davies Margaret L, Lloyd-Davies TA. Biblical leprosy: a comedy of errors. J Roy Soc Med, 1989; 82: $622-3$.

37 Bedi BMS. The ideal undergraduate curriculum in leprosy. Indian J Lepr, 1985; 60: 1-4.

38 McDougall AC. The medical student and leprosy. Lepr Rev, 1986; 57: 97-100.

39 McDougall AC, Georgiev GD. Prioritis in leprosy control. Lepr Rev, 1989; 60: 1-7.

40 Jopling WH. A continuing miracle: a report on five young women with HD. The $S T A R, 1981 ; 40$ (No. 6): 3-4.

41 Tare SP. Personal communication.

42 Skinsnes OK, Elvove RM. Leprosy in Society V. 'Leprosy' in occidental literature. Int J Lepr, 1970; 38: 294307. 